Electronic Supporting Information (ESI):

\title{
Non-oxidative strategy for monitoring peroxynitrite fluctuations in immune responses of tumorigenesis
}

Jiao Lu, ${ }^{\mathrm{a}}$ Zan Li ${ }^{\mathrm{a}}{ }^{*}$ Qing Gao, ${ }^{\mathrm{a}}$ Jiangkun Tan, ${ }^{\mathrm{a}}$ Zhiwei Sun, ${ }^{\mathrm{a}}$ Lingxin Chen, ${ }^{\mathrm{ab}}{ }^{*}$ Jinmao You $^{\text {ab* }}$

${ }^{a}$ Key Laboratory of Life-Organic Analysis of Shandong Province, School of Chemistry and Chemical Engineering, Qufu Normal University, Qufu 273165, P. R. China.

${ }^{b}$ CAS Key Laboratory of Coastal Environmental Processes and Ecological Remediation, Yantai Institute of Coastal Zone Research, Chinese Academy of Sciences, Yantai 264003, P. R. China.

*Correspondence authors: lilizanzan@163.com,jmyou6304@163.com,lxchen@yic.ac.cn

\begin{abstract}
Phagocyte respiratory burst in immune response generate enormous amounts of ROS to fulfill primary defense against neoplasia. However, the beneficial functions associated with ROS especially the potent oxidant/nucleophile peroxynitrite, in immunological process is still ambiguous. Herein we report the construction and biological assessment of cyanine-based fluorescent biosensors which were based on non-oxidative strategy for peroxynitrite detection. The established nonoxidative strategy is comprised of nucleophilic substitution and nano-aggregates formation initiated by peroxynitrite. The proposed non-oxidative strategy in this study could maintain cellular oxidative stress in the critical process of detection and preserve homeostasis of cell metabolism. The remarkable detection sensitivity, reaction selectivity, and spectral photo-stability of our biosensors enabled us to visualize endogenous peroxynitrite levels in immune stimulated phagocytes. With the aid of basal peroxynitrite imaging in an acute peritonitis model, the visualization of peroxynitrite level variations in immune response of tumorigenesis was accomplished assisted by our biosensors. It is envisioned that our strategy provided a promising tool for early tumor diagnosis and evaluation of tumor suppression in the process of immune responses without disturbing the functions of ROS signaling transduction.
\end{abstract}

KEY WORDS: Non-oxidative strategy; Fluorescence imaging; H-aggregates; Peroxynitrite; Immune responses; Tumorigenesis 


\section{Table of Contents}

General methods........................................................................

Spectroscopic data..............................................................

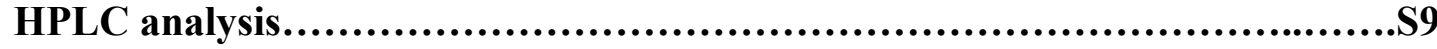

Molecular dynamics simulation.............................................S10

In vitro experiments...................................................... S11

In vivo experiments.....................................................S13

HR-MS and NMR spectra................................................S14

References...................................................................S18 


\section{Materials}

All the regents and materials including 3-morpholinosydnoniminehydrochloride (SIN1), 3, 3-bis (aminoethyl)-1-hydroxy-2-oxo-1-triazene (NOC-18), menadione sodium bisulfite (MSB), FeTMPyP, Lipopolysaccharides (LPS), interferon-gamma (IFN- $\gamma$ ), phorbol-12-myristate-13-acetate (PMA), aminoguanidine (AG) and apocynin were purchased from Sigma-Aldrich (USA). Analytical condition is the Tris-HCl buffered saline solution (20 mM, $\mathrm{pH}=7.4,10 \% \mathrm{DMSO})$.

\section{Determination of the in vitro detection limit}

The detection limit was calculated based on the fluorescence titration curve of $\mathrm{Cy}_{717}$ and $\mathrm{Cy}_{683}$. The fluorescence intensity of $\mathrm{Cy}_{717}$ and $\mathrm{Cy}_{683}$ was measured by ten times and the standard deviation of blank measurement was achieved. The detection limit was calculated with the following equation: ${ }^{1}$

$$
\text { Detection limit }=3 \sigma / \mathrm{k}
$$

Where $\sigma$ is the standard deviation of blank measurement, $\mathrm{k}$ is the slop between the fluorescence intensity versus $\mathrm{ONOO}^{-}$concentrations.

\section{Determination of quantum yields}

Cy717 and Cy683 were diluted to $10 \mu \mathrm{M}$ for absolute quantum yields (QY), and measurement was conducted by fluorometer (Edinburgh, FLS 1000). For Cy717, Ex $=720 \mathrm{~nm}$ and Cy683, Ex $=720$ nm. ${ }^{2}$

\section{Generation of ROS/RNS}

Dilution of $30 \%(10 \mathrm{~mol} / \mathrm{L})$ stock solution for $\mathrm{H}_{2} \mathrm{O}_{2}$. Dilution of $70 \%$ stock solution for tert-butyl hydroperoxide (TBHP). Dilution of $8 \%$ stock solution for $\mathrm{ClO}^{-}$. $\mathrm{ROO}$ was generated from AAPH (2, 2'-azo-bis (2-amidinopropane) dihydrochloride). $\mathrm{O}_{2}{ }^{-}$ was generated from $\mathrm{KO}_{2}$ in DMSO solution. $\mathrm{HO} \bullet$ was from the reaction of ferrous chloride $(1 \mu \mathrm{M})$ and $\mathrm{H}_{2} \mathrm{O}_{2}(100 \mu \mathrm{M})$. $\mathrm{NO}_{2}{ }^{-}$was from sodium nitrite. $\mathrm{NO}_{3}{ }^{-}$was from sodium nitrate. $\cdot N O$ was generated from Potassium Nitroprusside Dihydrate. $\mathrm{ONOO}^{-}$was prepared as reported, the $\mathrm{ONOO}^{-}$concentration was estimated by using an extinction coefficient of $1670 \pm 50 \mathrm{~cm}^{-1} \mathrm{M}^{-1}$ at $302 \mathrm{~nm} .^{3}$

\section{Cell viability assay}

RAW264.7 cells were cultured in a humidified incubator, which provided an 
atmosphere of $5 \% \mathrm{CO} 2$ and $95 \%$ air at $37{ }^{\circ} \mathrm{C}$. The culture medium was DMEM (Dulbecco's modified Eagle's medium, Gibco BRL) medium, which contained $10 \%$ FBS (fetal bovine serum, Gibco BRL), $100 \mu \mathrm{g} / \mathrm{mL}$ streptomycin (Gibco BRL), and $100 \mathrm{U} / \mathrm{mL}$ penicillin (Gibco BRL). The inhibitory concentration of the compounds toward RAW264.7 cell line was evaluated by MTT assay. Cells were seeded in a 96well plate at $5 \times 10^{3}$ cells/well and allowed to grow $12 \mathrm{~h}$ prior to exposure to different concentrations of tested compounds for further $24 \mathrm{~h} .20 \mu \mathrm{L}$ of MTT solution/per well ( $5 \mathrm{mg} / \mathrm{mL}$ ) was added and the cells were incubated for further $4 \mathrm{~h}$, DMSO (150 $\mu \mathrm{L} /$ well) was then added for $10 \mathrm{~min}$ after removing the total medium. The absorbance at $490 \mathrm{~nm}$ was collected using a Varioskan Flash microplate reader.

\section{Transmission electron microscope}

$10 \mathrm{ml}$ of Cy683 $(10 \mu \mathrm{M})$ in Tris-HCl buffer solution $(20 \mathrm{mM}$, DMSO/Tris- $\mathrm{HCl}=1: 9$ $v / v, \mathrm{pH} 7.4$ ) was added $\mathrm{ONOO}^{-}$(total concentration was $2.5 \mu \mathrm{M}$ ). The resultant solution was dropped into the copper screen. After the solution was dried, TEM images were captured with JEM-2100 PLUS.

\section{LC-MS Analysis}

After the reaction of $\mathrm{Cy} 717$ and $\mathrm{ONOO}^{-}$, the solution was collected for LC-MS analysis. HPLC analysis used a linear gradient from $20 \%$ methanol/ $80 \% \mathrm{H}_{2} \mathrm{O}$ to 80 $\%$ methanol $/ 20 \% \mathrm{H}_{2} \mathrm{O}$ over 15 min using Agilent G6460A LC-MS spectrometer, Hypersil BDS, C18, $5 \mu \mathrm{m}, 4.6 \times 250 \mathrm{~mm}$ column.

\section{Molecular dynamics simulations}

First-principle calculations were based on density functional theory (DFT), which was performed using Gaussian 09 program to derive the atomic electrostatic potential fit charges of Cy683. The details were as follows: Geometry optimization of Cy683 was performed at B3LYP/6-31G(d) level. 


\section{Spectroscopic data}
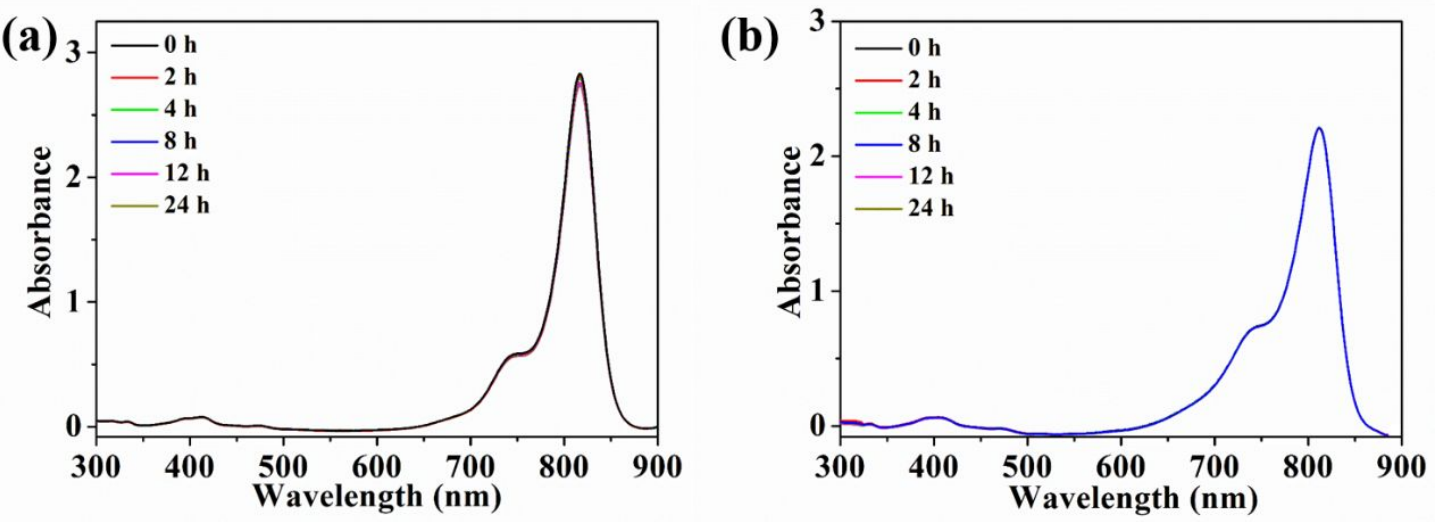

Figure S1. The absorbance spectra of (a) $\mathrm{Cy}_{683}(10 \mu \mathrm{M})$ and (b) $\mathrm{Cy}_{717}(10 \mu \mathrm{M})$ at different times in Tris-HCl buffer solution.
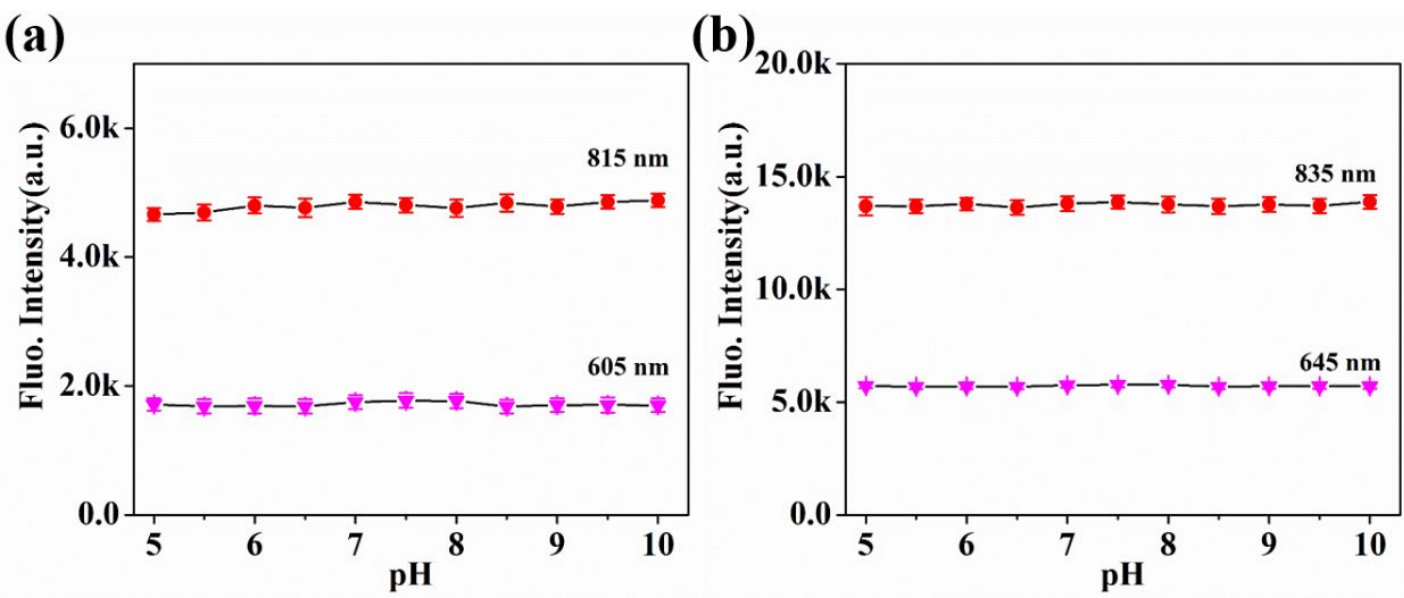

Figure S2. Fluorescence intensity of (a) Cy717 (10 $\mu \mathrm{M})$ and (b) Cy683 $(10 \mu \mathrm{M})$ as a function of $\mathrm{pH}$. Slit width $3 \mathrm{~nm}$, excitation wavelength was $550 \mathrm{~nm}$ and $720 \mathrm{~nm}$.
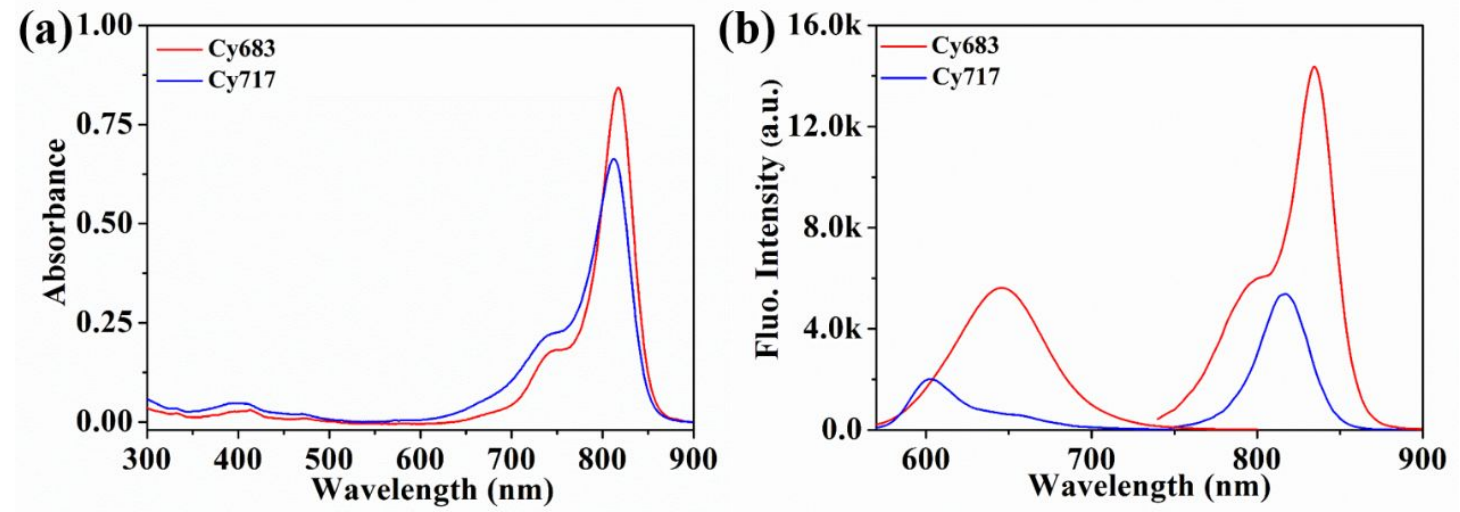
Figure S3. (a) UV-visible spectra of $\mathrm{Cy}_{717}(10 \mu \mathrm{M})$ and $\mathrm{Cy}_{683}(10 \mu \mathrm{M})$ in buffer solution. (b) Fluorescence emission spectra of $\mathrm{Cy}_{717}(10 \mu \mathrm{M})$ and $\mathrm{Cy}_{683}(10 \mu \mathrm{M})$ in buffer solution. All measurements were taken at $37^{\circ} \mathrm{C}$.

\section{Cy717}

\section{Quantum Yield Results}

for 'Multi Scans (QY)'

Scatter Range: 714.00 to $727.00 \mathrm{~nm}$ Emission Range: 738.00 to $875.00 \mathrm{~nm}$

$$
\mathrm{QY}=11.16 \%
$$

\section{Cy683}

Quantum Yield Results for 'Multi Scans (QY)'

Scatter Range: 715.00 to $726.00 \mathrm{~nm}$ Emission Range: 739.00 to $900.00 \mathrm{~nm}$

$$
\mathrm{QY}=17.72 \%
$$

Figure S4. Fluorescence quantum yields of Cy717 $(10 \mu \mathrm{M})$ and Cy683 $(10 \mu \mathrm{M})$ in buffer solution. All measurements were taken at $37^{\circ} \mathrm{C}$.
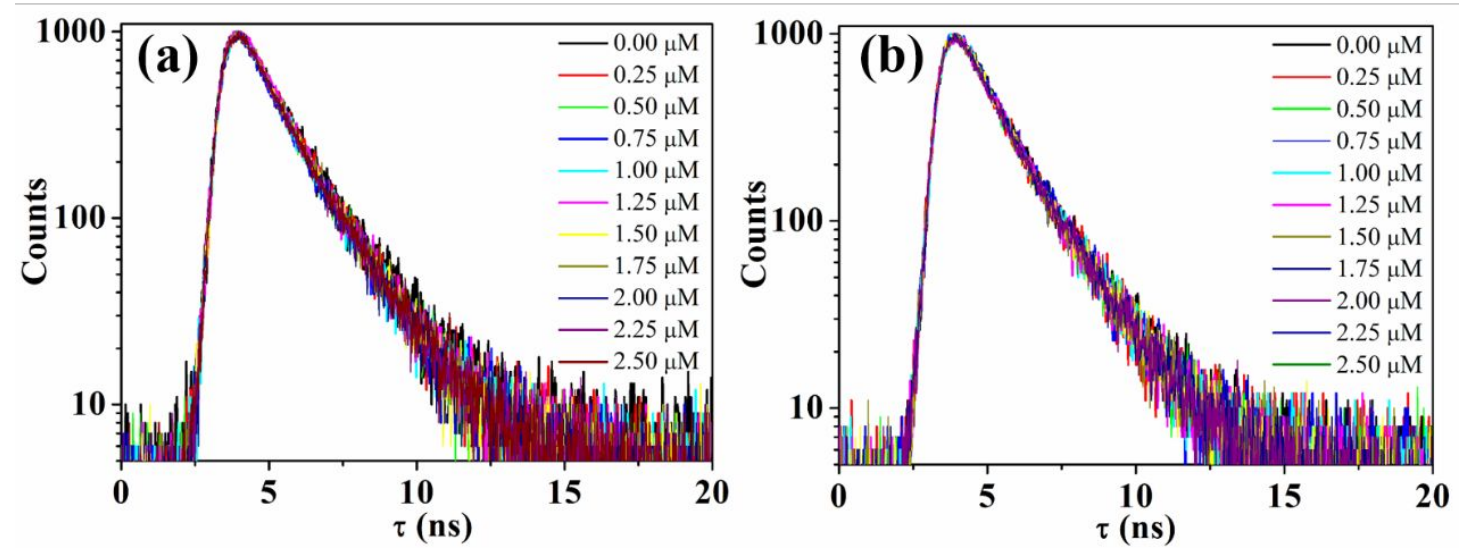

Figure S5. Fluorescence life time spectra of (a) Cy717 (10 $\mu \mathrm{M})$ and (b) Cy683 (10 $\mu \mathrm{M})$ in Tris- $\mathrm{HCl}(0.02 \mathrm{M})$ solution after adding concentrations of $\mathrm{ONOO}^{-}$in 20 minutes. Ex. $543 \mathrm{~nm}$.

(a)

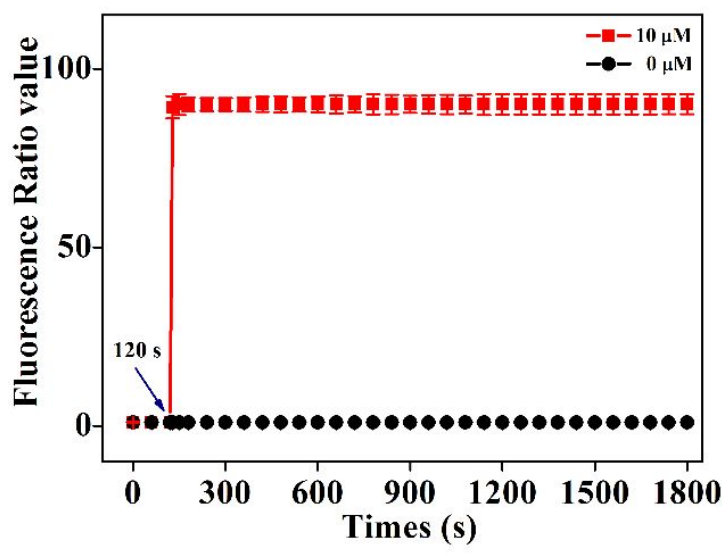

(b)

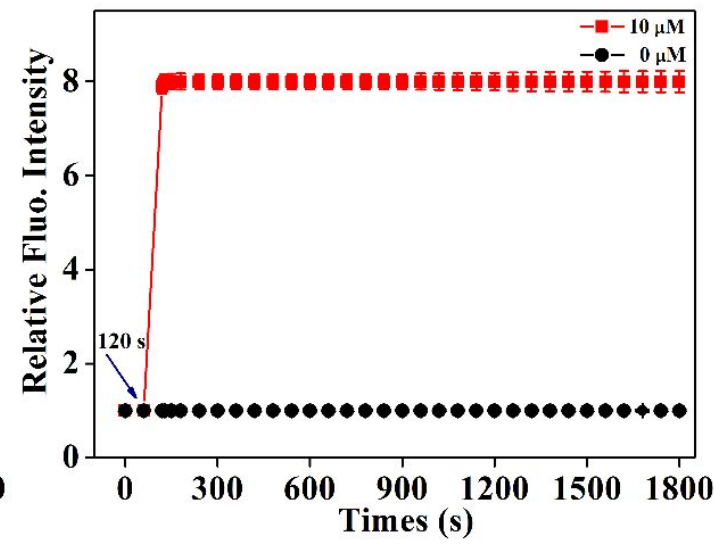


Figure S6. Time dependent fluorescence responses of (a) Cy717 $(10 \mu \mathrm{M})$ and (b)

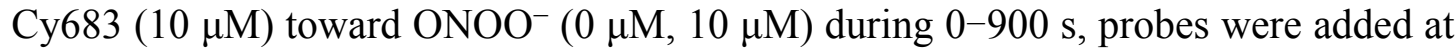
120 s. The error bars represent \pm S.D. $(n=3)$.

(a)

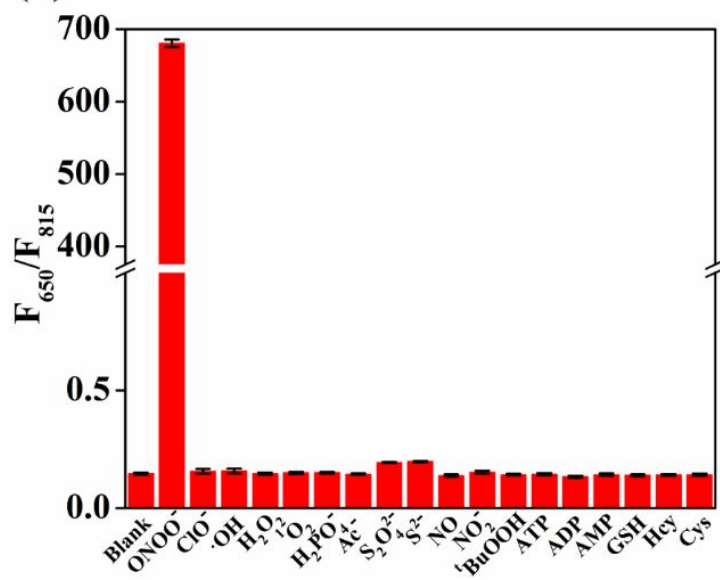

(b)

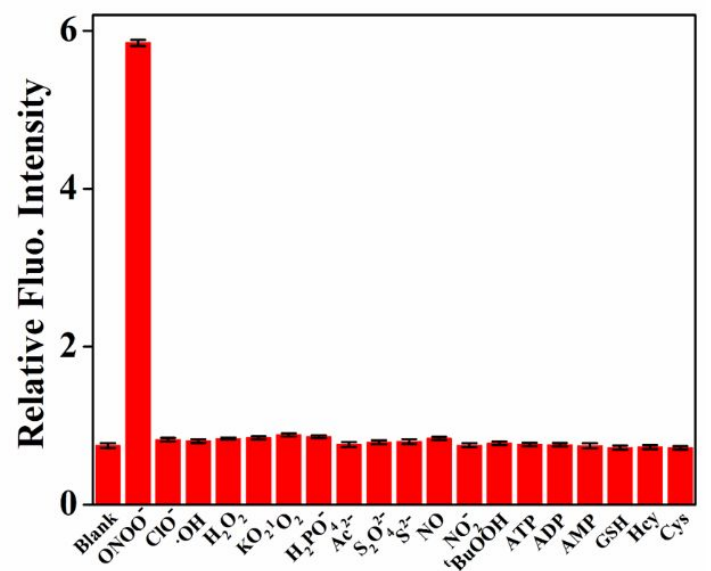

Figure S7. (a) Ratiometric fluorescence responses (F650/F815) of Cy717 (10 $\mu \mathrm{M})$ toward $\mathrm{ONOO}^{-}$(1 equivalent) and other ROS/RNS/RSS (100 equivalents). (b) Relative fluorescence responses $(\mathrm{F} 815)$ of Cy683 $(10 \mu \mathrm{M})$ toward $\mathrm{ONOO}^{-}(1$ equivalent) and other ROS/RNS/RSS (100 equivalents). The error bars represent \pm S.D. $(n=3)$.
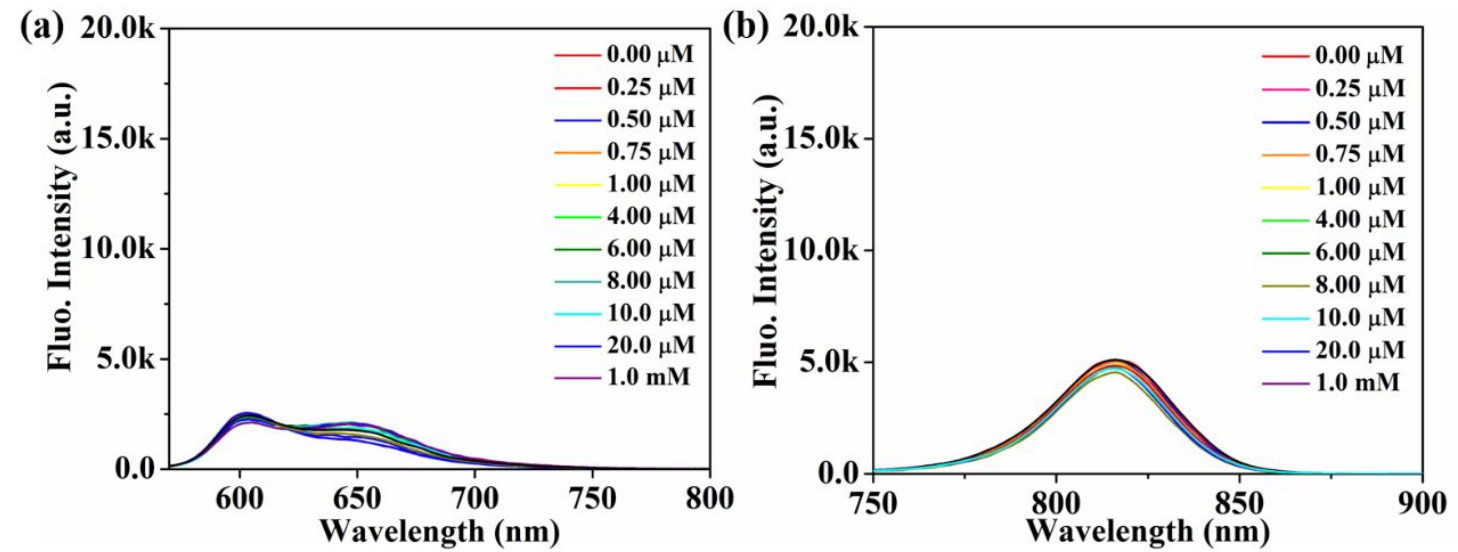

Figure S8. Fluorescence responses of Cy717 $(10 \mu \mathrm{M})$ in Tris- $\mathrm{HCl}(0.02 \mathrm{M})$ solution with titration of sodium sulfide (0-1.0 mM). (a) Emission peaks at $602 \mathrm{~nm}$, Ex. 550 nm. (b) Emission peaks of $815 \mathrm{~nm}$, Ex. $720 \mathrm{~nm}$. All measurements were taken at $37^{\circ} \mathrm{C}$. The data were recorded 20 minutes after sodium sulfide was added. 


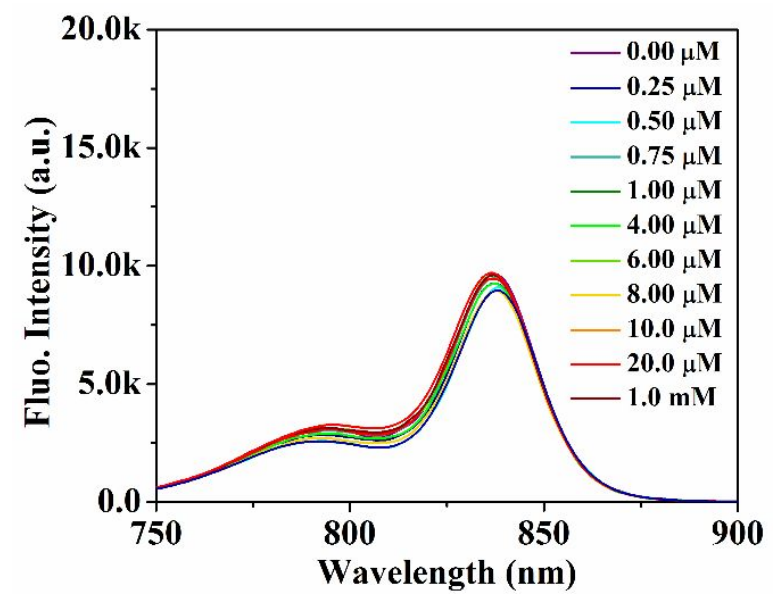

Figure S9. Fluorescence responses of $\mathrm{Cy} 683(10 \mu \mathrm{M})$ in Tris- $\mathrm{HCl}(0.02 \mathrm{M})$ solution with titration of sodium sulfide $(0-1.0 \mathrm{mM})$. Ex. $720 \mathrm{~nm}$. All measurements were taken at $37^{\circ} \mathrm{C}$. The data were recorded 20 minutes after sodium sulfide was added.

(a)

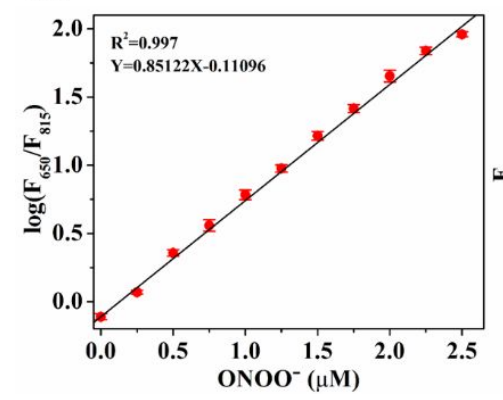

(b)

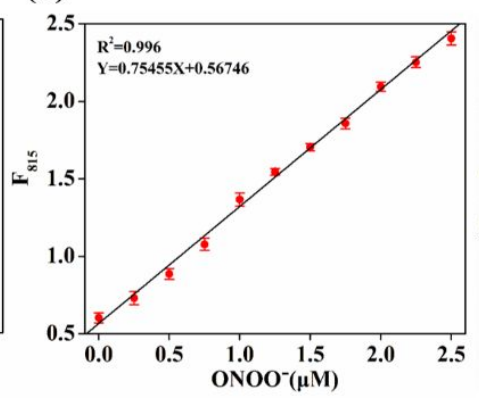

(c)

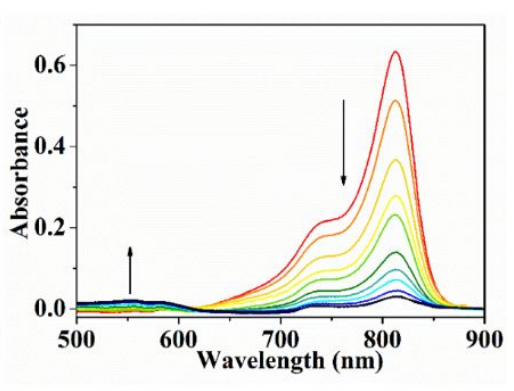

Figure S10. (a) The linear relationship between $\log (\mathrm{F} 650 \mathrm{~nm} / \mathrm{F} 815 \mathrm{~nm})$ and concentrations of $\mathrm{ONOO}^{-}$. (b) The linear relationship between F815 and concentrations of $\mathrm{ONOO}^{-}$. (c) $\mathrm{UV}$-visible spectra of Cy717 $(10 \mu \mathrm{M})$ in Tris- $\mathrm{HCl}$ $(0.02 \mathrm{M})$ solution with titration of $\mathrm{ONOO}^{-}\left(0^{-} 2.5 \mu \mathrm{M}\right)$. All measurements were taken at $37^{\circ} \mathrm{C}$. The data were recorded 20 minutes after $\mathrm{ONOO}^{-}$was added. The error bars represent \pm S.D. $(n=3)$. 


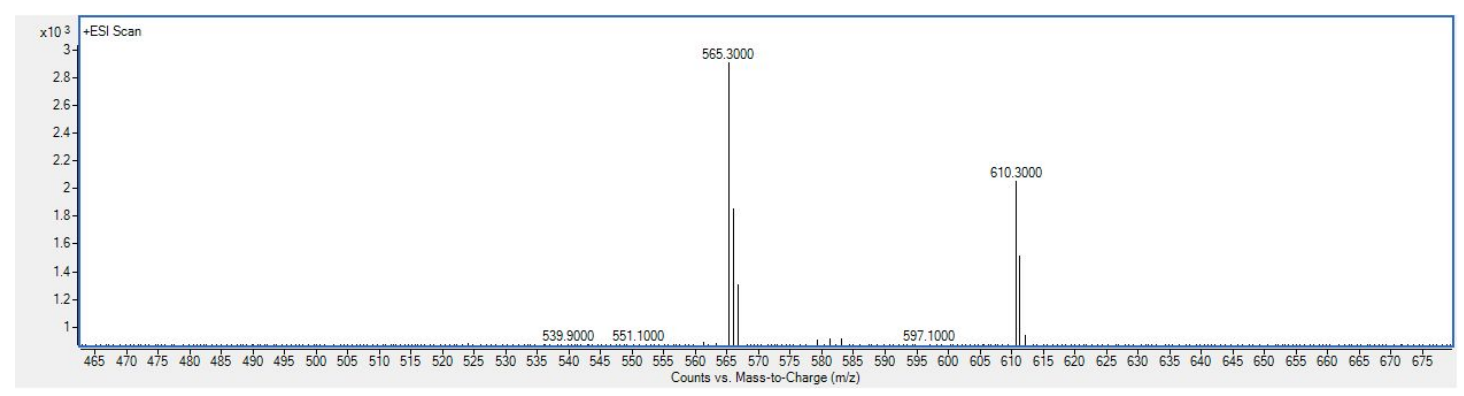

Figure S11. ESI-MS spectrum of Cy565 and the intermediate compound, Enol A

\section{HPLC analysis}

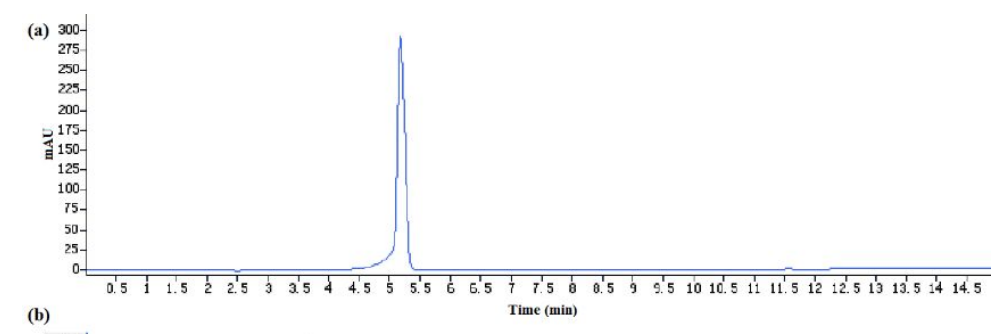

(b)

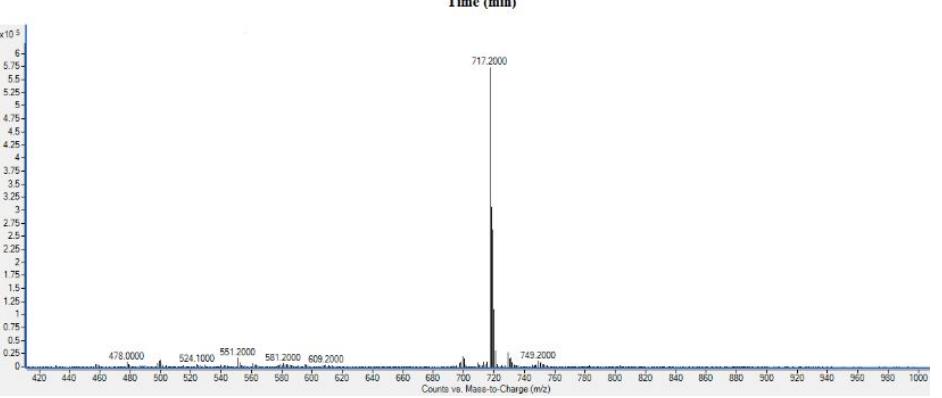

Figure S12. LC-MS for Cy717. HPLC runs used a linear gradient from $20 \%$ methanol $/ 80 \% \mathrm{H}_{2} \mathrm{O}$ to $80 \%$ methanol $/ 20 \% \mathrm{H}_{2} \mathrm{O}$ over 15 minutes using Agilent G6460A LC-MS spectrometer, Hypersil BDS, C18, $5 \mu \mathrm{m}, 4.6 \times 250 \mathrm{~mm}$ column. (a) Chromatogram of Cy717. (b) ESI-MS spectrum of Cy717.
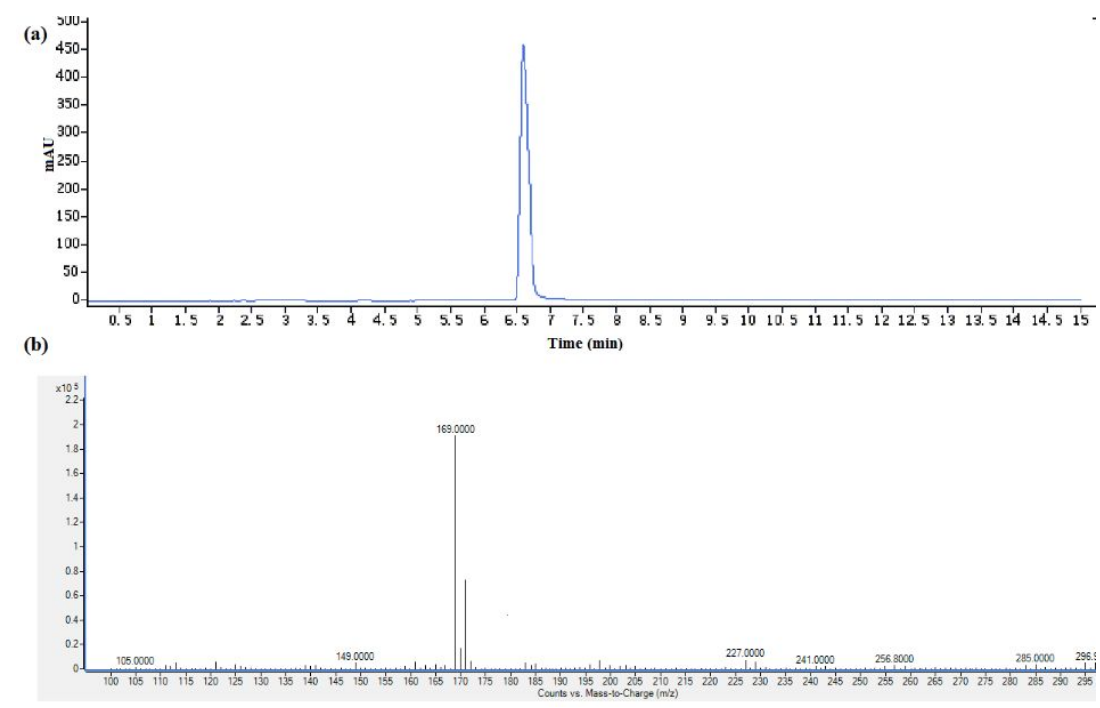
Figure S13. LC-MS for CMB-Acid. HPLC runs used a linear gradient from $20 \%$ methanol $/ 80 \% \mathrm{H}_{2} \mathrm{O}$ to $80 \%$ methanol $/ 20 \% \mathrm{H}_{2} \mathrm{O}$ over 15 minutes using Agilent G6460A LC-MS spectrometer, Hypersil BDS, C18, 5 $\mu \mathrm{m}, 4.6 \times 250 \mathrm{~mm}$ column. (a) Chromatogram of CMB-Acid. (b) Negative mode ESI-MS spectrum of CMB-Acid.

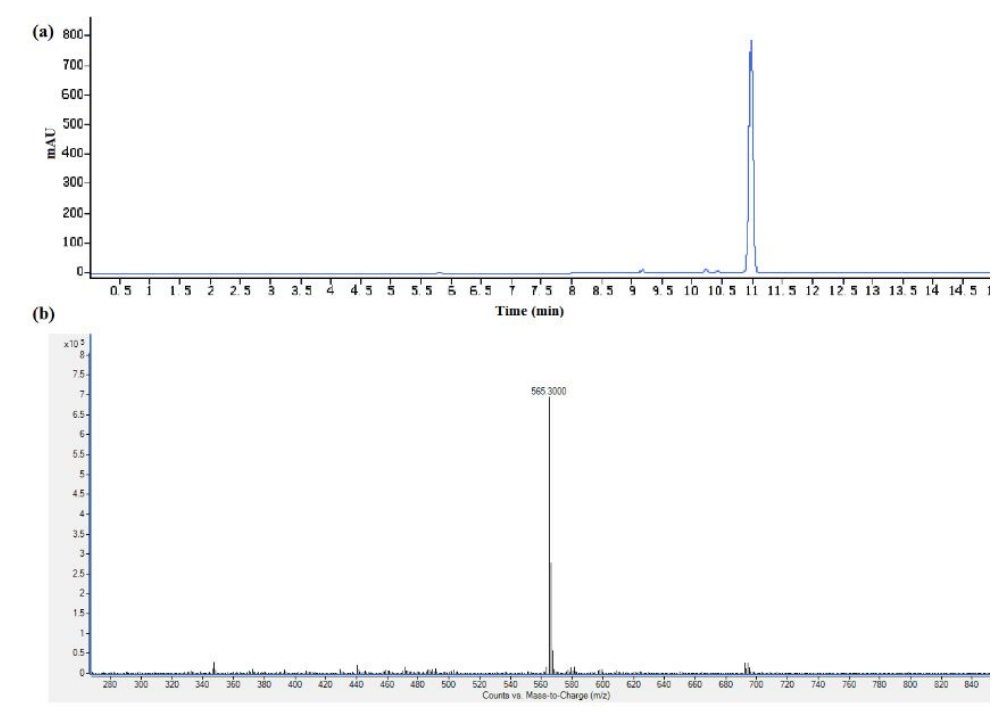

Figure S14. LC-MS for Cy565. HPLC runs used a linear gradient from $20 \%$ methanol $/ 80 \% \mathrm{H}_{2} \mathrm{O}$ to $80 \%$ methanol $/ 20 \% \mathrm{H}_{2} \mathrm{O}$ over 15 minutes using Agilent

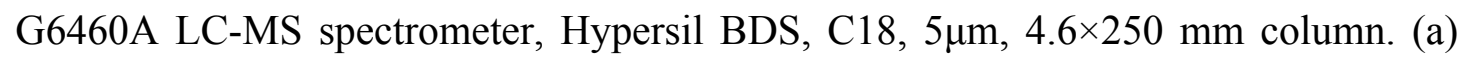
Chromatogram of Cy565. (b) ESI-MS spectrum of Cy565.

\section{Molecular dynamics simulation}

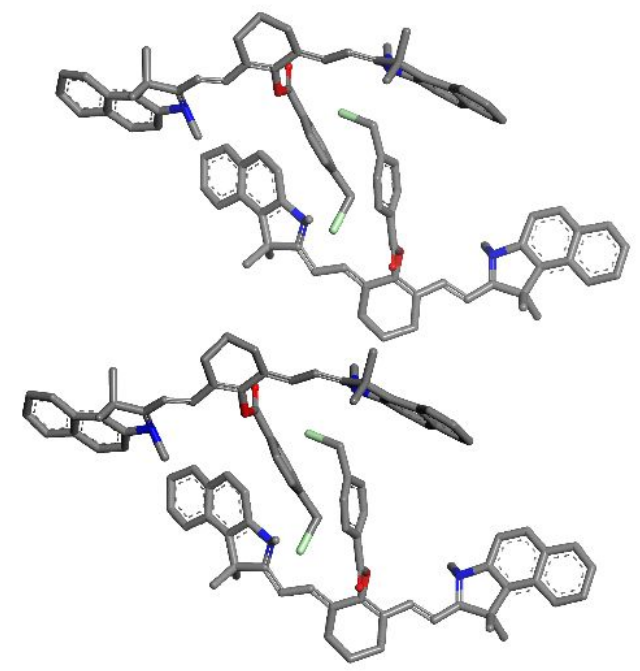

Figure S15. Molecular dynamics simulation of Cy717 in aqueous solution. 


\section{In vitro experiments}
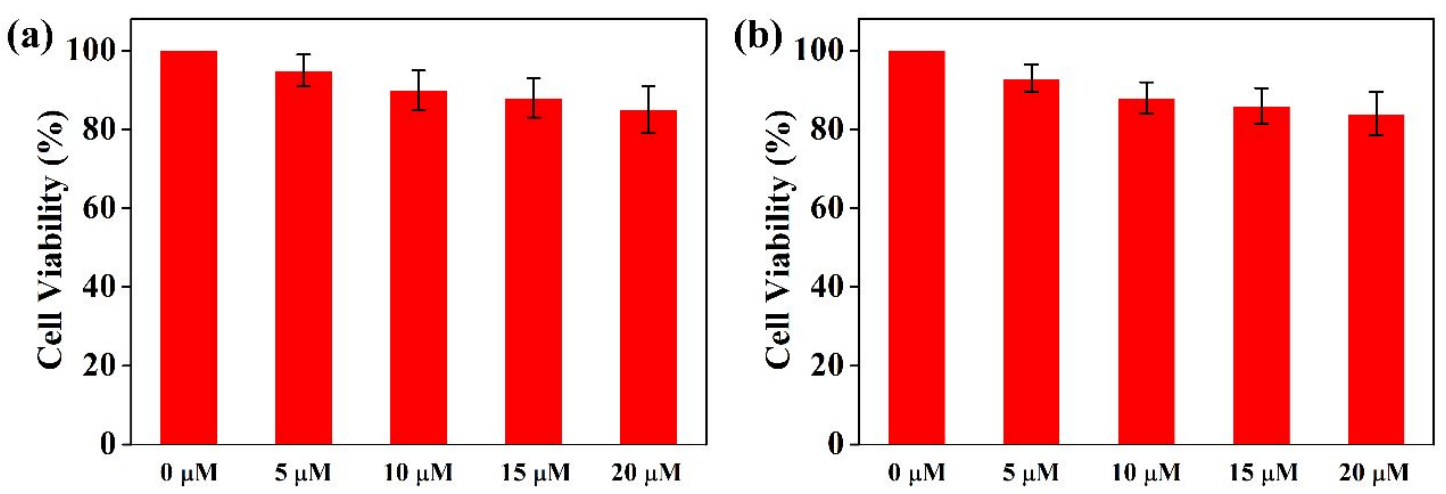

Figure S16. Cytotoxic effects of (a) Cy717 and (b) Cy683. RAW 264.7 cells were incubated with various concentrations of probes for $24 \mathrm{~h}$. Cell viability was evaluated with MTT test. The error bars represent \pm S.D. $(n=6)$.

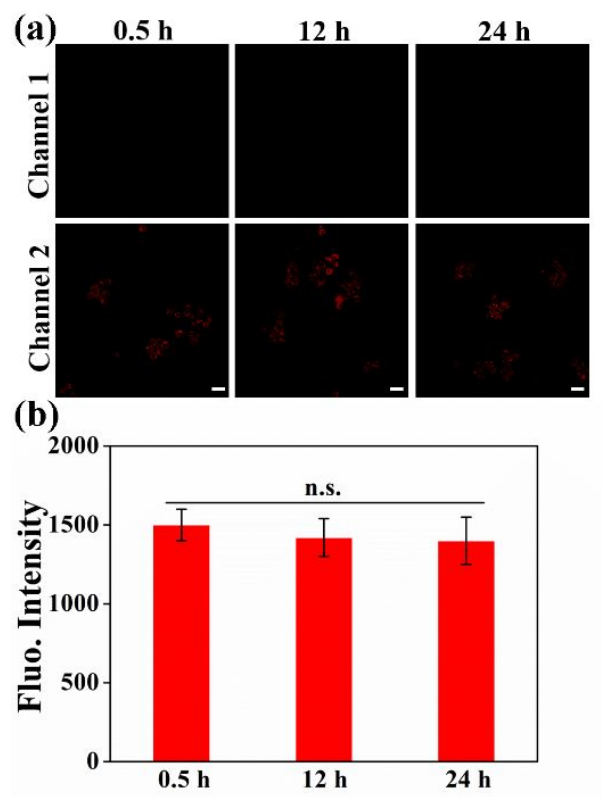

Figure S17. (a) Confocal fluorescence images of RAW 264.7 macrophages incubated with Cy717 $(10 \mu \mathrm{M})$ at different time points: $0.5 \mathrm{~h}, 12 \mathrm{~h}, 24 \mathrm{~h}$. Images were acquired by using channel 1: $\lambda_{\mathrm{ex}}=543 \mathrm{~nm}, \lambda_{\mathrm{em}}=560-750 \mathrm{~nm}$, channel 2: $\lambda_{\mathrm{ex}}=720 \mathrm{~nm}$, $\lambda_{\mathrm{em}}=750-850 \mathrm{~nm}$. (b) The corresponding fluorescence intensities of group (a). Scale bar represents $10 \mu \mathrm{m}$. 


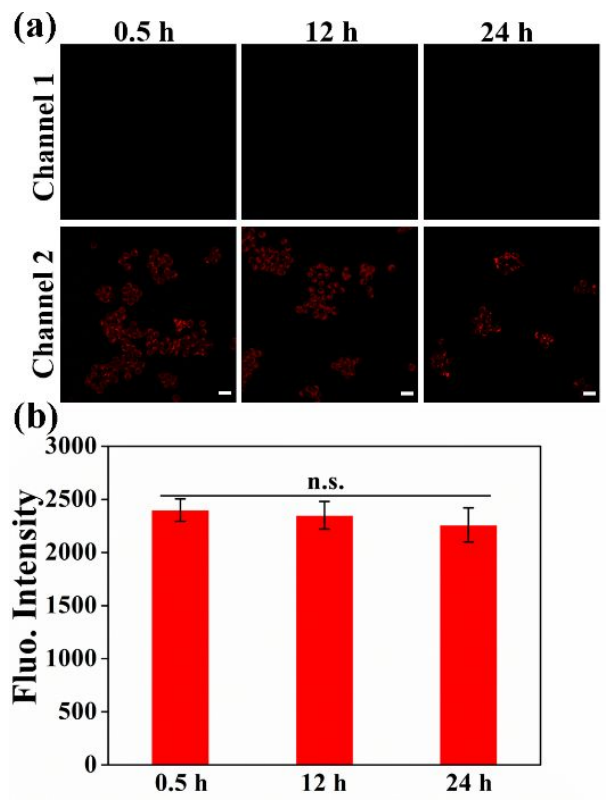

Figure S18. (a) Confocal fluorescence images of RAW 264.7 macrophages incubated with Cy683 $(10 \mu \mathrm{M})$ at different time points: 0.5 h, 12 h, $24 \mathrm{~h}$. Images were acquired by using channel 1: $\lambda_{\mathrm{ex}}=543 \mathrm{~nm}, \lambda_{\mathrm{em}}=560-750 \mathrm{~nm}$, channel $2: \lambda_{\mathrm{ex}}=720 \mathrm{~nm}, \lambda_{\mathrm{em}}=750^{-}$ $850 \mathrm{~nm}$. (b) The corresponding fluorescence intensities of group (a). Scale bar represents $10 \mu \mathrm{m}$.

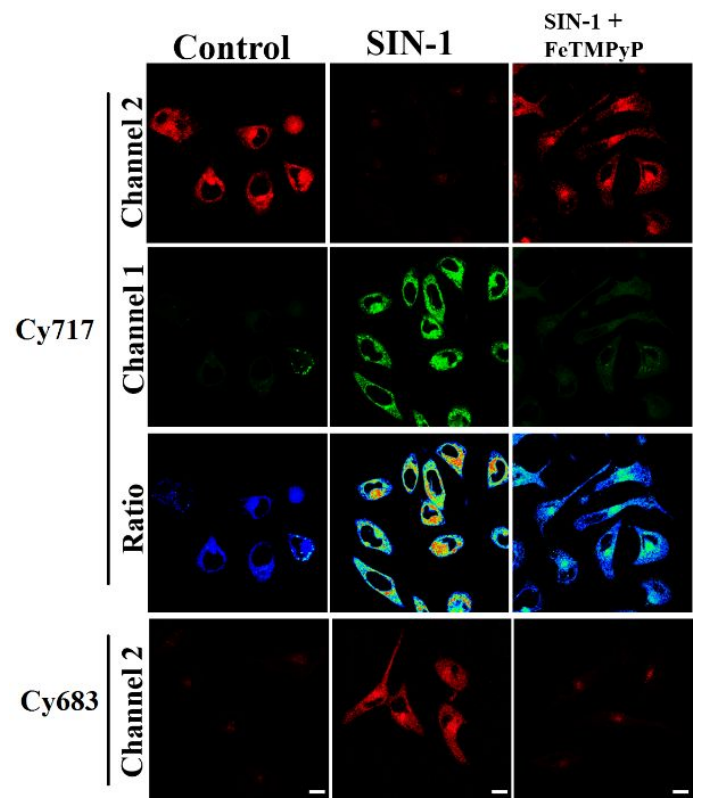

Figure S19. Evaluation of exogenous $\mathrm{ONOO}^{-}$detection by $\mathrm{Cy} 717(10 \mu \mathrm{M})$ and Cy683 $(10 \mu \mathrm{M})$ through confocal imaging in HepG-2 cells. Cells were loaded with Cy717 and Cy683 for 30 min respectively, and then treated with SIN-1 (50 $\mu \mathrm{M})$, FeTMPyP $(50 \mu \mathrm{M})$ was used to decomposite $\mathrm{ONOO}^{-}$. The pseudo-color images 
illustrated the ratio values of channel 1 versus channel 2. Images were acquired by using channel 1: $\lambda_{\mathrm{ex}}=543 \mathrm{~nm}, \lambda_{\mathrm{em}}=560-750 \mathrm{~nm}$, channel $2: \lambda_{\mathrm{ex}}=720 \mathrm{~nm}, \lambda_{\mathrm{em}}=750-850$ $\mathrm{nm}$. Scale bar represents $10 \mu \mathrm{m}$.

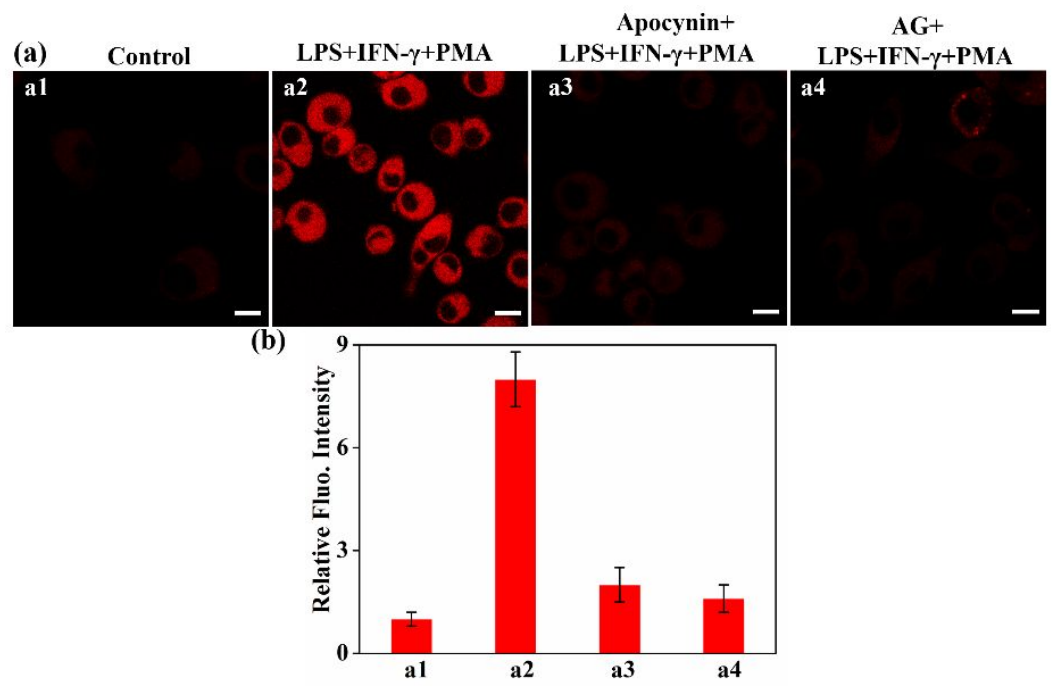

Figure S20. Confocal fluorescence images of RAW264.7 cells exposed to immune stimulus. Cells were treated with immune stimulus and then loaded with $10 \mu \mathrm{M}$ Cy683 for 30 minutes. (a1) Control. (a2) LPS ( $1 \mu \mathrm{g} / \mathrm{mL})$ and IFN- $\gamma(100 \mathrm{ng} / \mathrm{mL})$ for $16 \mathrm{~h}$, followed by PMA (500 nM) for $1 \mathrm{~h}$. (a3) Apocynin $(100 \mu \mathrm{M})$ for $1 \mathrm{~h}$, LPS (1 $\mu \mathrm{g} / \mathrm{mL})$ and IFN- $\gamma(100 \mathrm{ng} / \mathrm{mL})$ for $16 \mathrm{~h}$, followed by PMA $(500 \mathrm{nM})$ for $1 \mathrm{~h}$. (a4) AG $(5 \mathrm{mM})$ for $4 \mathrm{~h}$, LPS $(1 \mu \mathrm{g} / \mathrm{mL})$ and IFN- $\gamma(100 \mathrm{ng} / \mathrm{mL})$ for $16 \mathrm{~h}$, followed by PMA (500 nM) for $1 \mathrm{~h}$. (b) The corresponding relative fluorescence intensity of group (a). Scale bar represents $10 \mu \mathrm{m}$.

\section{In vivo experiments}

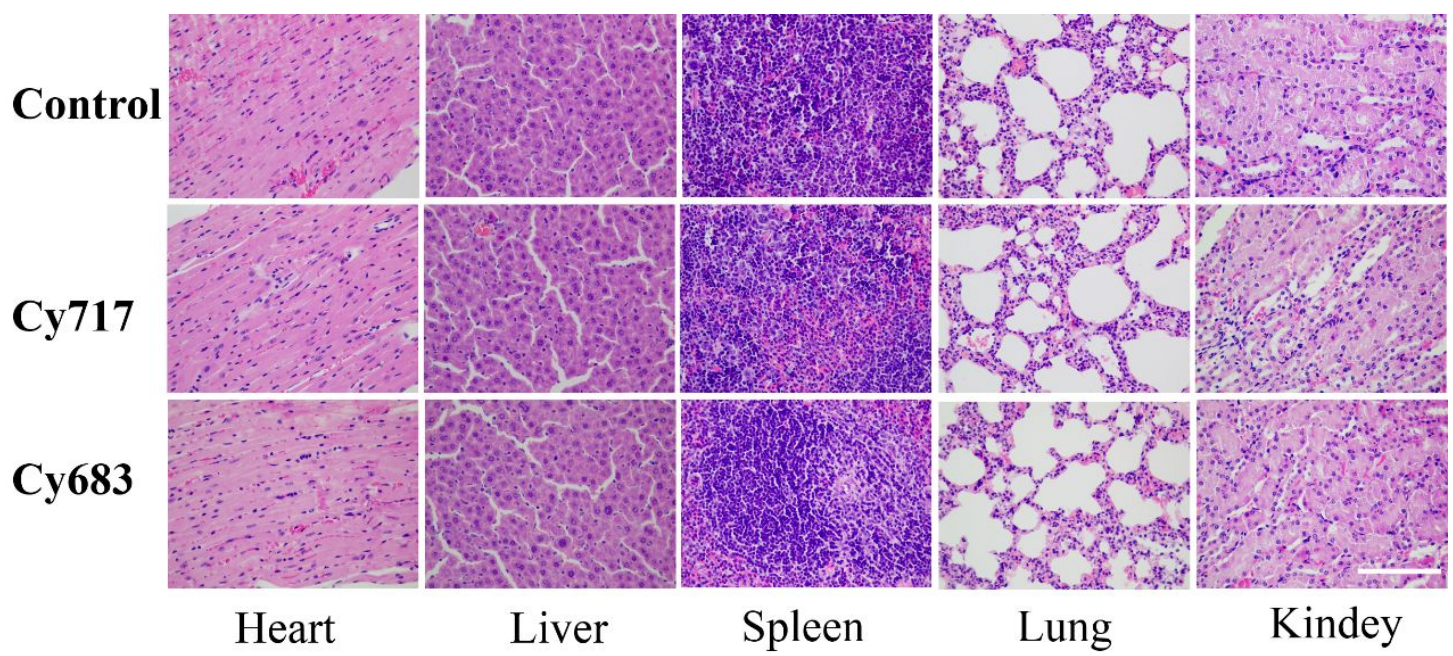


Figure S21. H\&E staining of main organs from control mouse (above) and treated mouse after 24 hours' administration. Cy717 (1 mM in saline, $20 \mu \mathrm{L})$ and Cy683 (1 $\mathrm{mM}$ in saline, $20 \mu \mathrm{L}$ ) were intravenously injected in the tail. Scale bar: $200 \mu \mathrm{m}$.

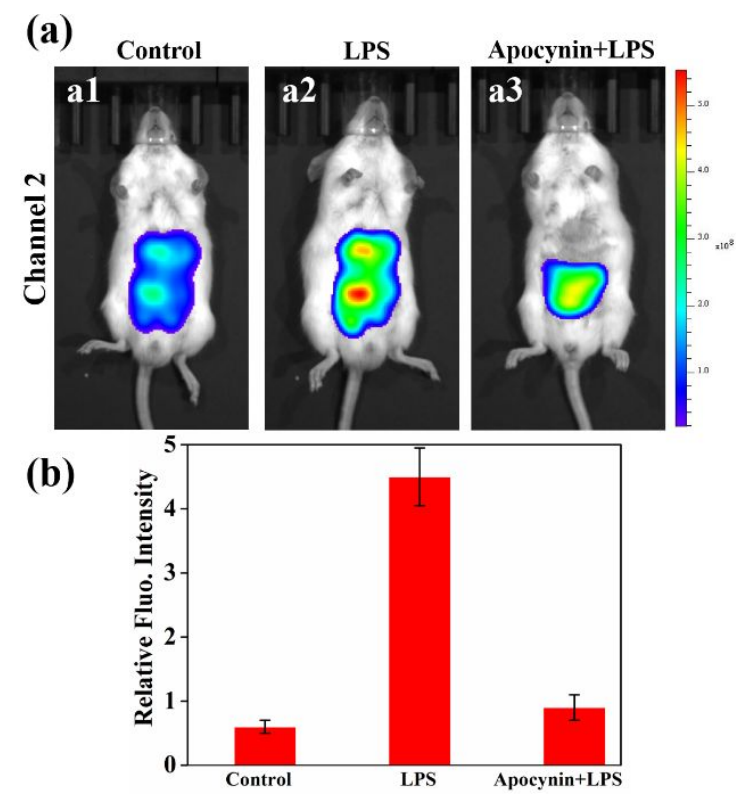

Figure S22. Imaging of endogenous $\mathrm{ONOO}^{-}$fluxes in acute inflammatory mice. Cy683 was injected in the inflamed site, images were acquired at 30 minutes after the injection. Channel 2: Ex. $720 \mathrm{~nm}$, Em. 750-900 nm. (a1) The control group were treated with saline. (a2) Mice were stimulated with LPS for 4 h. (a3). Mice were treated with apocynin, and then stimulated with LPS. (b) The corresponding relative fluorescence intensity of group (a). The error bars represent \pm S.D. $(n=3)$.

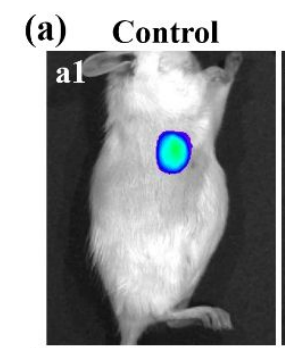

(b)

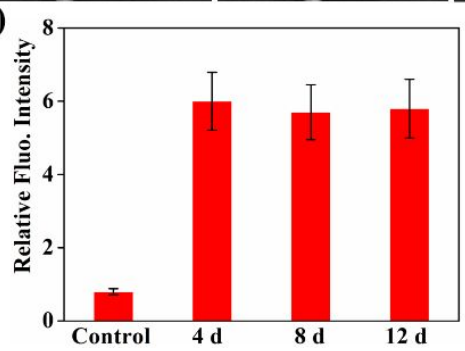

$4 \mathrm{~d}$

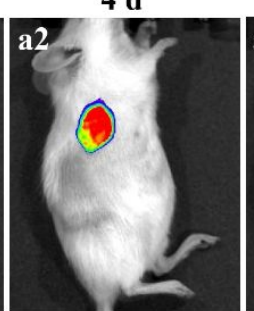

(c)

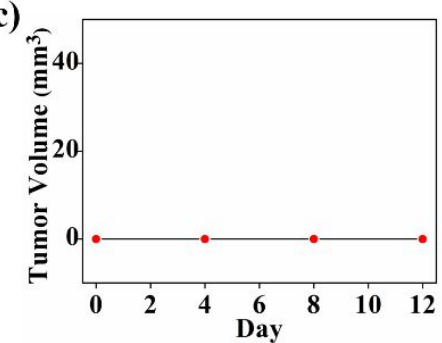


Figure S23. In vivo imaging of endogenous $\mathrm{ONOO}^{-}$generation in the immune responses of tumorigenesis. Cy683 was injected in the adjacent tumor cell-injected sites, images were acquired at 30 minutes after the injection. Channel 2: Ex. $720 \mathrm{~nm}$, Em. 750-900 nm. (a1) Fluorescence images of tumor cell-injected mice. The image was captured after the cells were injected immediately. (a2) The 4th day after the tumor cells were injected. (a3) The 8th day after the tumor cells were injected. (a4) The 12th day after the tumor cells were injected. (b) The quantitative relative fluorescence intensity of group (a). (c) The volume values of HepG-2 tumors in group (a). The error bars represent \pm S.D. $(n=3)$.

\section{HR-MS and NMR spectra}

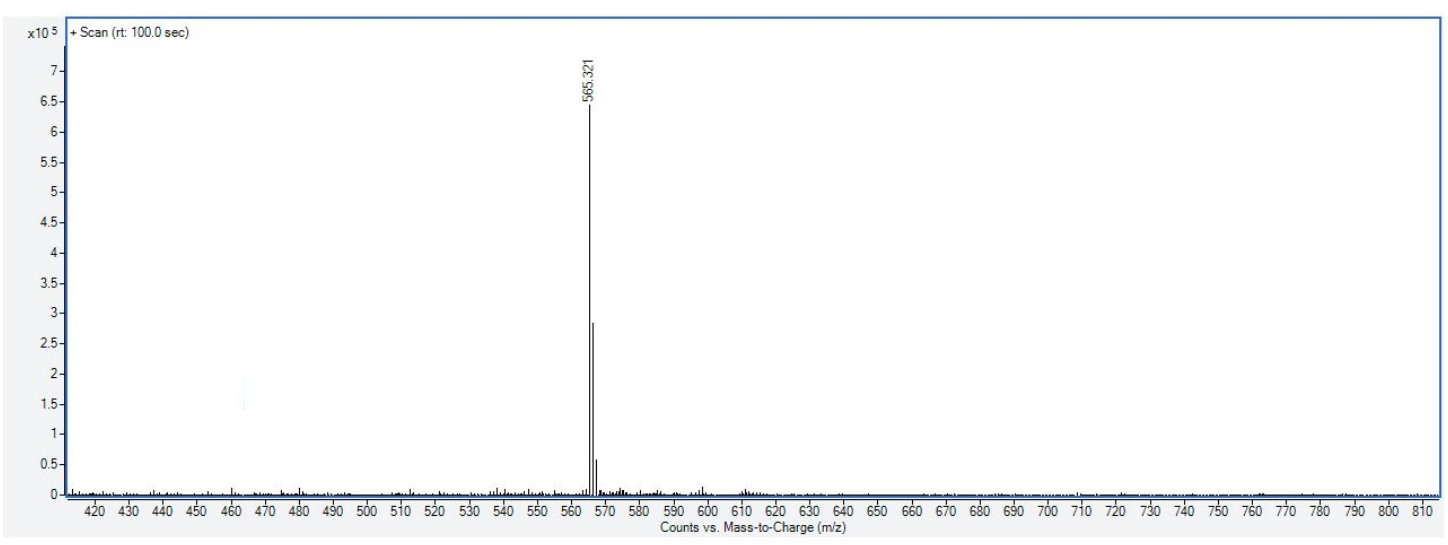

Figure S24. HR-MS spectrum of Cy565 in methanol

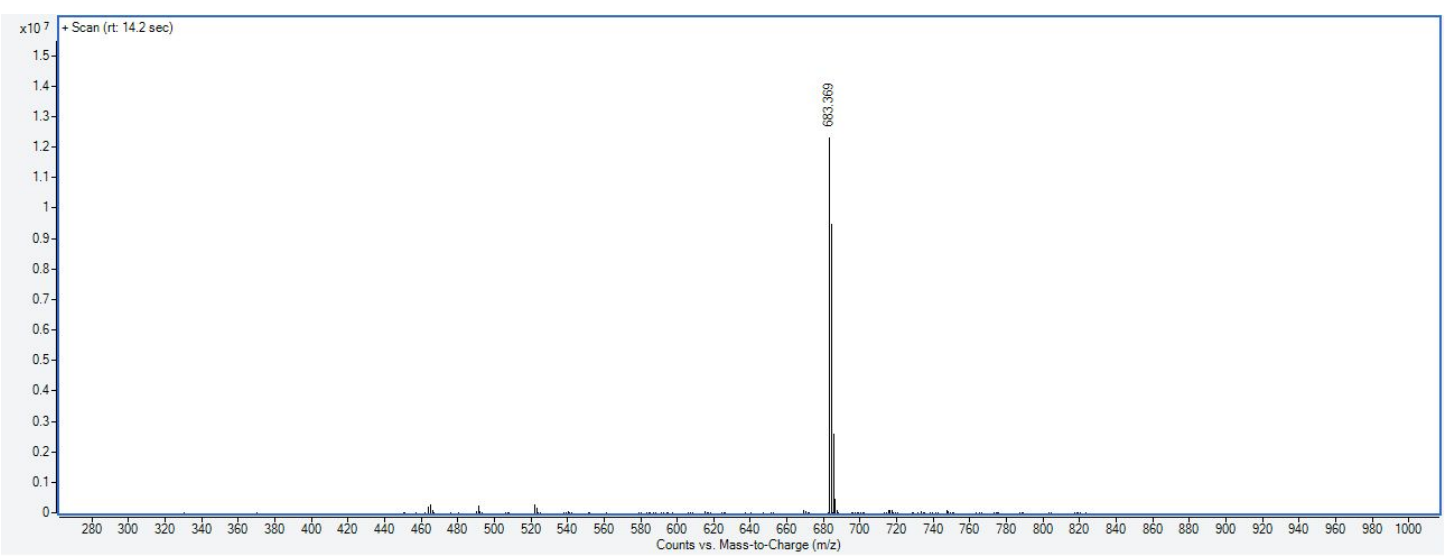

Figure S25. HR-MS spectrum of Cy683 in methanol 


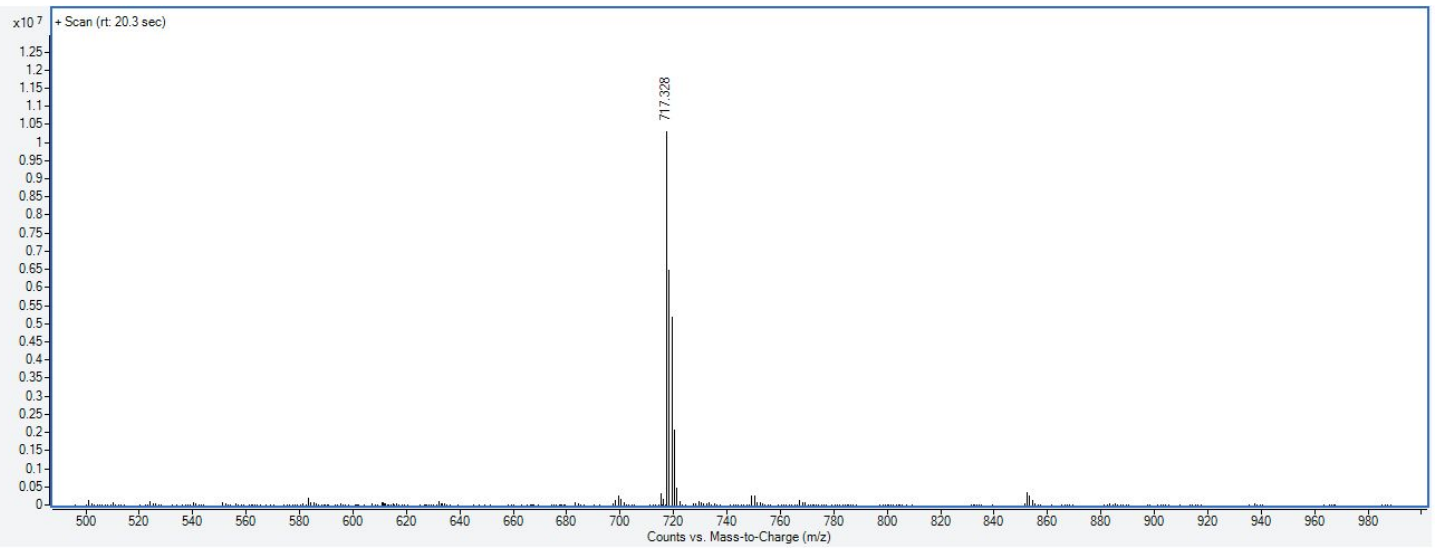

Figure S26. HR-MS spectrum of Cy717 in methanol

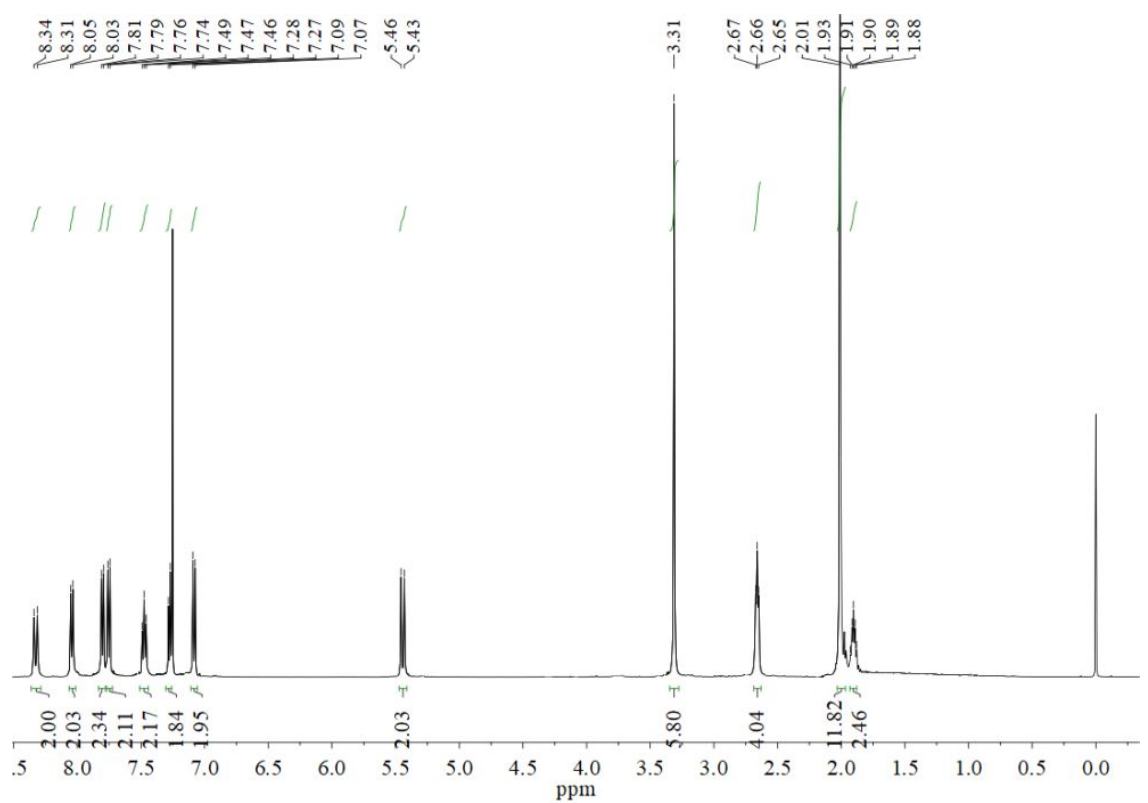

Figure S27. ${ }^{1} \mathrm{H}$ NMR of Cy565 in $\mathrm{CDCl}_{3}$ 


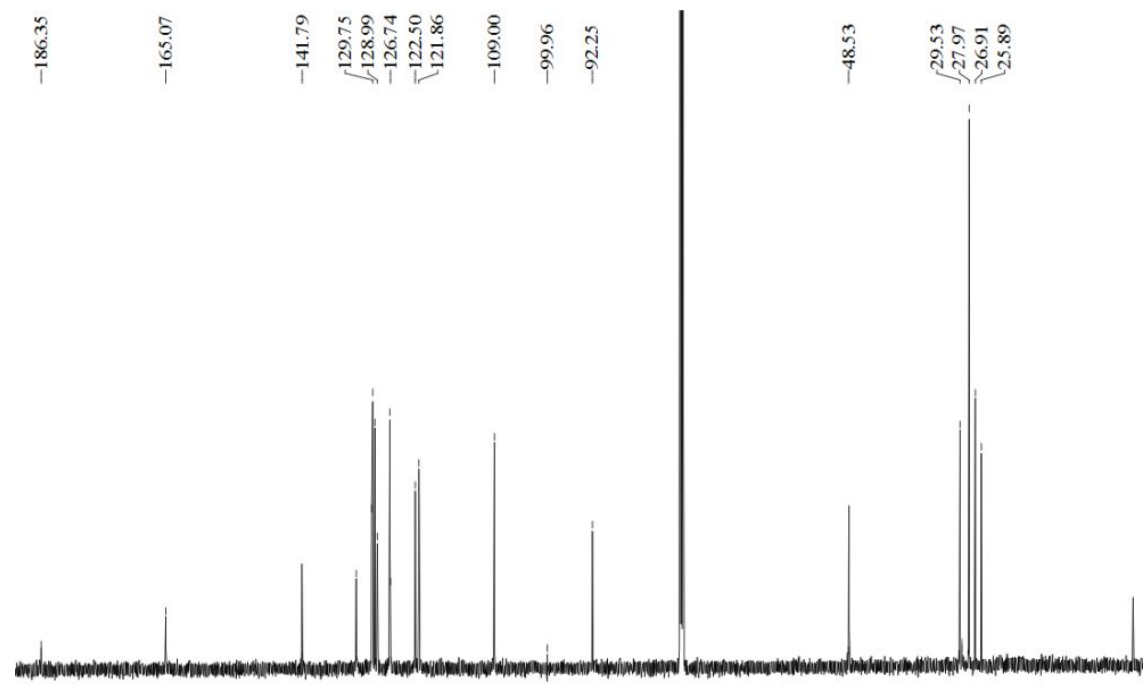

$\begin{array}{lllllllllllllllllllllll}90 & 180 & 170 & 160 & 150 & 140 & 130 & 120 & 110 & 100 & 90 & 80 & 70 & 60 & 50 & 40 & 30 & 20 & 10 & 0\end{array}$

Figure S28. ${ }^{13} \mathrm{C}$ NMR of Cy565 in $\mathrm{CDCl}_{3}$

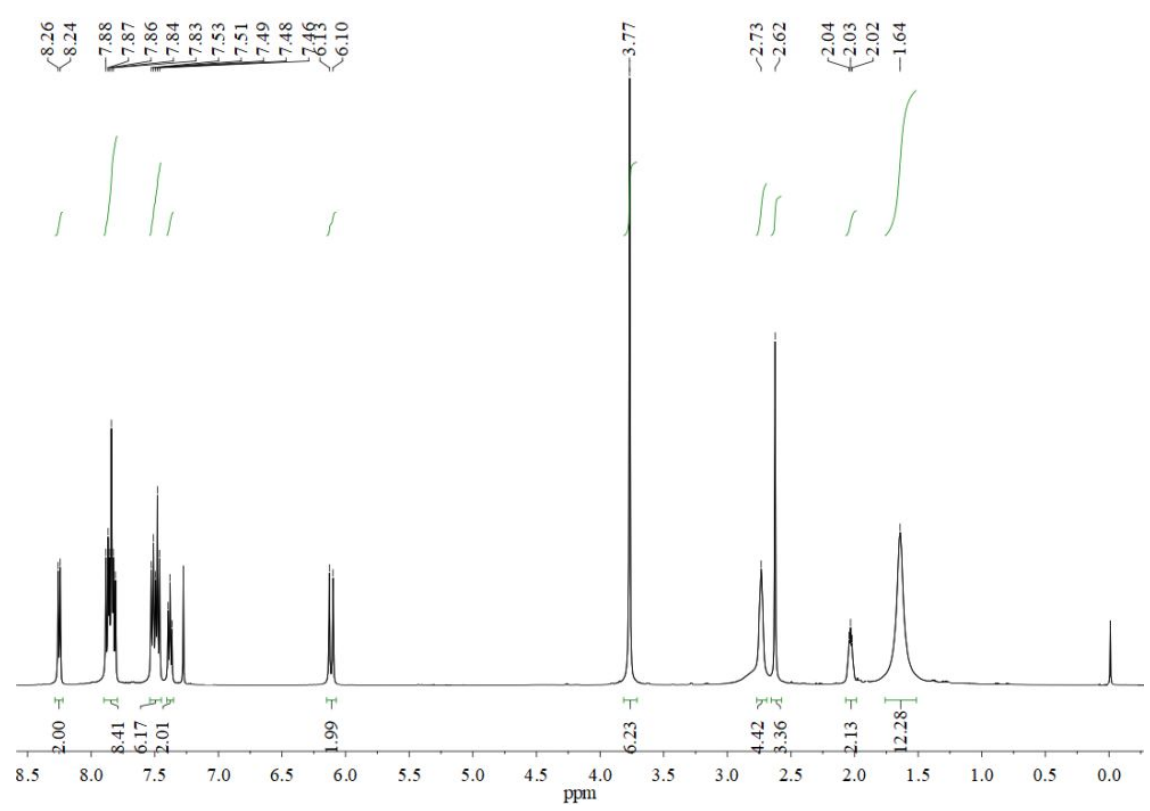

Figure S29. ${ }^{1} \mathrm{H}$ NMR of Cy683 in $\mathrm{CDCl}_{3}$ 


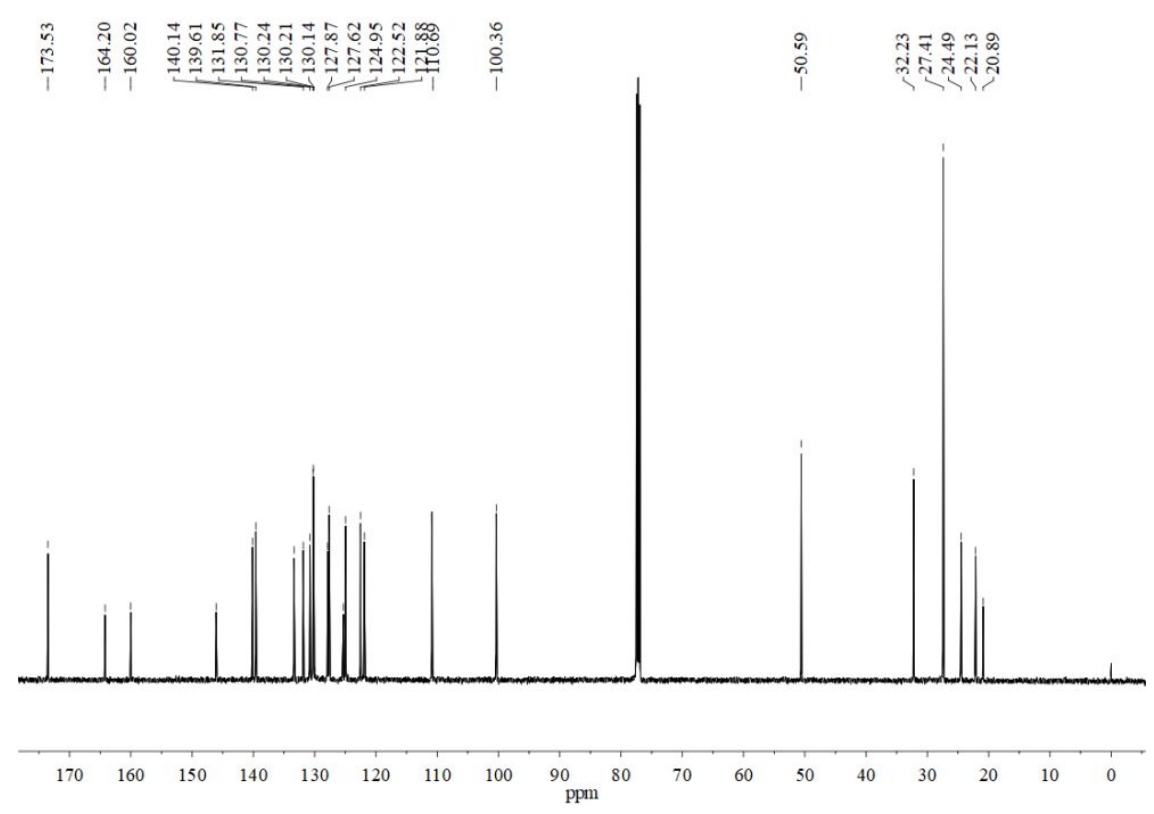

Figure S30. ${ }^{13} \mathrm{C}$ NMR of $\mathrm{Cy} 683$ in $\mathrm{CDCl}_{3}$

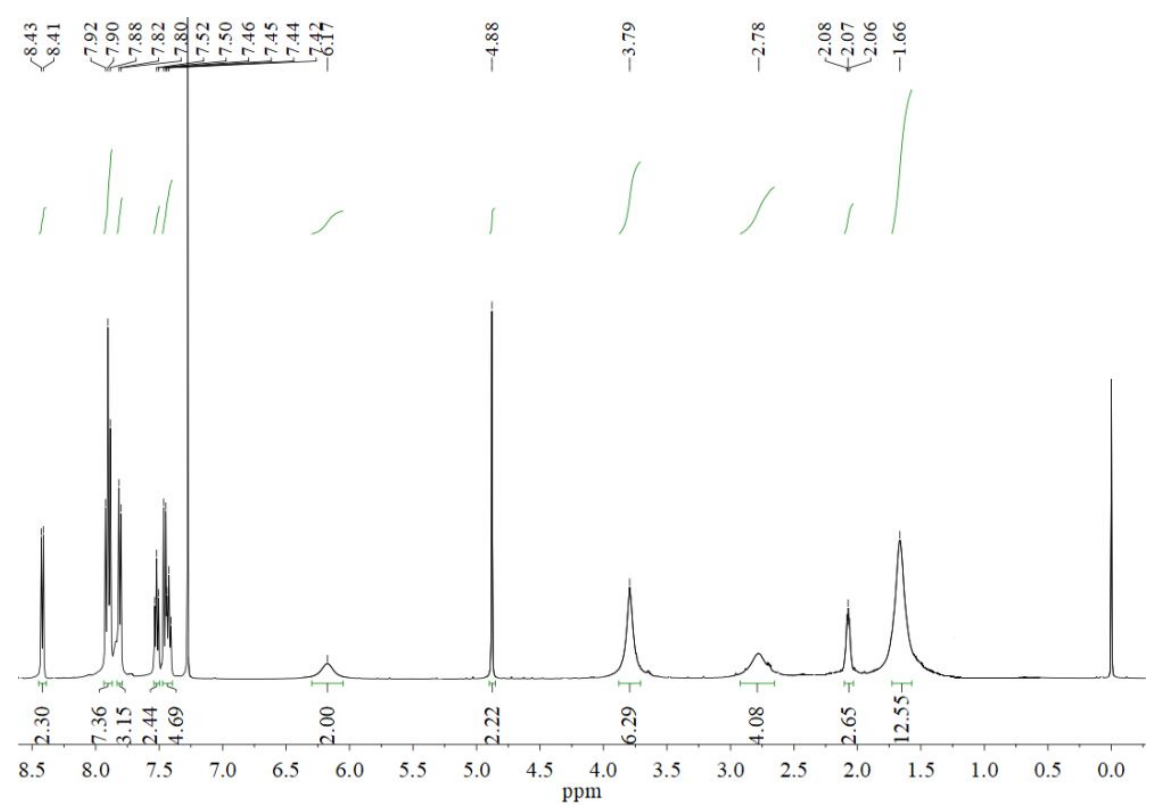

Figure S31. ${ }^{1} \mathrm{H}$ NMR of $\mathrm{Cy} 717$ in $\mathrm{CDCl}_{3}$ 


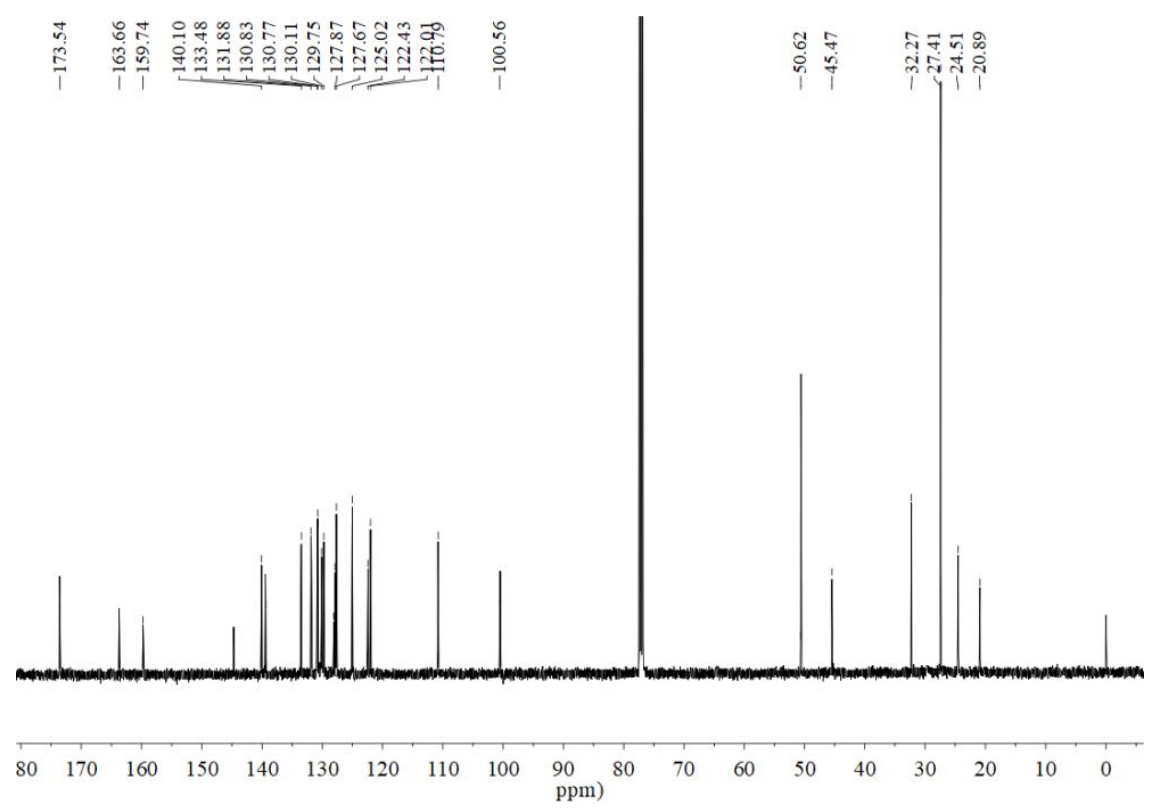

Figure S32. ${ }^{13} \mathrm{C}$ NMR of $\mathrm{Cy} 717$ in $\mathrm{CDCl}_{3}$

\section{References}

(1) Zhu, H.; Fan, J.; Wang, J.; Mu, H.; Peng, X., J. Am. Chem. Soc. 2014, 136, 12820.

(2) Brewer, T. F.; Chang, C. J., J. Am. Chem. Soc. 2015, 137, 10886.

(3) Peng, T.; Wong, N. K.; Chen, X.; Chan, Y. K.; Ho, D. H.; Sun, Z.; Hu, J. J.; Shen, J.; El-Nezami, H.; Yang, D., J. Am. Chem. Soc. 2014, 136, 11728. 